\title{
PROGRAM HOLISTIK E-LEARNING DI PERGURUAN TINGGI ISLAM
}

\author{
Erika Kusumaputri \\ Program Studi Psikologi Fakultas Ilmu Sosial dan Humaniora \\ Universitas Islam Negeri Sunan Kalijaga \\ Jalan Marsda Adisucipto No. 1 Yogyakarta 55281 \\ erikakusumaputri@yahoo.co.id
}

\begin{abstract}
The purpose of this study was to identify the Critical Success Factors Model for implementing e-learning in the Islamic university and to propose strategies derived from the perspective of holistic, consultative, and emancipatory. Analysis of CSF was trying to uphold the organization using research methods to identify the purpose of management as essential elements that were important in achieving the effectiveness of the change process. Data were analyzed from depth interviews and focused group discussion with university leaders, chief of Puskom, and quality assurance unit, referred to the number of CSF, which were grouped into 4 groups, namely: leadership, structural and cultural design, technology, and delivery of content. The result of this study shows that every element of higher education institutions is prepared to be able to attach them to $e$-learning in supporting the development of career or profession. So, we need the ability of universities to manage the change process through discussions with the proposed design objectives (goal).
\end{abstract}

Keywords: critical success factors, depth interview, e-learning, focus group, holistic

\begin{abstract}
Abstrak
Tujuan penelitian adalah untuk mengidentifikasi Critical Success Factors (CSF) Model terhadap implementasi e-learning di perguruan tinggi Islam dan untuk mengusulkan strategi yang diperoleh dari perspektif holistik, konsultatif, dan emansipatori. Analisis organisasi menggunakan CSF berusaha menegakkan metode penelitian manajemen dengan maksud untuk mengidentifikasi elemen-elemen esensial yang penting dalam mencapai efektivitas proses perubahan. Data dianalisis dari hasil wawancara
\end{abstract}


mendalam dan diskusi kelompok terarah dengan para pimpinan universitas, ketua puskom, dan unit penjaminan mutu (quality assurance), mengacu pada sejumlah indikator CSF yang dibagi menjadi empat kelompok, yaitu: kepemimpinan, struktural dan budaya; rancangan, teknologi, dan penyampaian materi. Hasil penelitian menunjukkan bahwa setiap unsur institusi perguruan tinggi dipersiapkan untuk mampu melekatkan diri dengan e-learning dalam mendukung pengembangan karir atau profesi, sehingga diperlukan kemampuan universitas untuk mengelola proses perubahan dengan mengusulkannya melalui diskusi perancangan tujuan (goal).

Katakunci: Critical Success Factors, Diskusi Kelompok Terarah, ELearning, Holistik, Wawancara Mendalam.

\section{Pendahuluan}

Surat Keputusan Menteri Pendidikan Nasional No. 107/U/2001 dengan jelas membuka koridor untuk menyelenggarakan pendidikan jarak jauh yang di dalamnya E-Learning dapat memainkan peran pada lembaga dan organisasi pendidikan di Indonesia. Respon aktif dan kreatif terkait dengan penggunaan teknologi informasi dalam proses pembelajaran akan menandakan bahwa lembaga pendidikan khususnya perguruan tinggi harus menyesuaikan diri dengan perkembangan zaman. Lembaga pendidikan, khususnya perguruan tinggi harus memiliki kemampuan national competitiveness (kompetisi nasional) untuk menyesuaikan diri dengan paradigma perguruan tinggi yang dikenal dengan Higher Education Long Term Strategy (HELTS) 2003-2010, dan salah satu penentu keunggulan daya saing adalah penggunaan teknologi informasi yang digunakan sebagai sarana pembelajaran.

E-learning membawa pengaruh yang sangat besar terhadap terjadinya proses transformasi pendidikan yang semula diberikan secara konvensional, beralih menggunakan sarana digital, baik secara konten maupun sistem. Menurut Harley \& Knight (1996) e-learning merupakan suatu kondisi belajar yang memungkinkan tersampaikannya bahan ajar ke mahasiswa dengan menggunakan media internet, intranet atau media jaringan komputer. Disimpulkan bahwa e-learning adalah penggunaan setiap bentuk teknologi atau aplikasi dalam layanan pembelajaran atau fasilitas bagi para pelajar. Saat ini penerapan $e$-learning cukup penting karena $e$ learning dapat menimbulkan pengaruh yang signifikan, antara lain membantu mengetahui bagaimana siswa belajar, seberapa cepat menguasai ketrampilan, 
sejauhmana suatu materi mudah untuk dipelajari; dan yang tidak kalah pentingnya, seberapa jauh mereka menikmati proses pembelajaran. Pentingnya $e$-learning membuat institusipendidikan segera melakukan transformasipendidikan, salah satunya mengoptimalisasi penggunaan teknologi untuk memenuhi tuntutan dan fenomena globalisasi yang sangat menekankan kompetisi dalam kebanyakan sektor industri, termasuk pendidikan.

Konsekuensi penggunaan teknologi informasi pada institusi pendidikan, khususnya perguruan tinggi, tidak hanya berkonsentrasi pada penyiapan sarana prasarana berupa perangkat keras (hardware) saja, tidak kalah pentingnya adalah pengelolaan (management) yang cukup hati-hati (McPherson, 2003), yaitu menggunakan strategi organisasional yang tepat. Penelitian tentang pengelolaan teknologi informasi (IT management) menunjukkan bahwa implementasi sistem informasi mempersyaratkan perlunya strategi perencanaan tipe baru (Spil dan Salmela, 1999). Dalamkonteks ini, rencana strategik melibatkan pandangan holistik dan dinamis untuk mengelola semua aspek terkait implementasi sistem informasi. Hingga saat ini penelitian tentang e-learning pada perguruan tinggi belum pernah menghasilkan model yang holistik dalam melibatkan semua aspek organisasi untuk mendukung terlaksananya impelementasi $e$-learning di perguruan tinggi. Model dalam pengelolaan holistik implementasi e learning menekankan pada critical success factors, yang direpresentasikan menggunakan empat kuandran, yaitu (1) kepemimpinan (leadership), struktural, permasalahan budaya; (2) permasalahan rancangan, khususnya terkait dengan e-learning sesuai setting institusi; (3) teknologi, dikhususkan pada aspek electrical pada $e$-learning; dan (4) proses pembelajaran, yaitu pada implementasi e learning

Dalam merespon tantangan yang dihadapi dunia pendidikan, birokrasi di Indonesia merancang dan menegakkan perubahan peraturan pada pendidikan tinggi. Perubahan peraturan mencakup dua hal utama, yaitu : (1) perubahan struktur tanggung jawab dalam pengawasan pendidikan tinggi; dan (2) dampak pada pelaksanaan pengawasan pendidikan tinggi.

Perubahan yang cukup mencolok antara sistem pengelolaan pendidikan yang mengacu pada UU Sisdiknas lama dan baru adalah pengelolaan organisasi pendidikan yang bersifat otonomi. Hal ini diatur dalam pasal 24 ayat 2 yang menyatakan bahwa perguruan tinggi memiliki otonomi untuk mengelola sendiri lembaganya sebagai pusat penyelenggaraan pendidikan tinggi, penelitian ilmiah, dan pengabdian kepada masyarakat. Pasal 50 ayat (6) menyatakan bahwa perguruan tinggi menentukan kebijakan dan memiliki otonomi dalam mengelola pendidikan di lembaganya. 
Penjelasan pasal 50 ayat (6) bahwa yang dimaksud dengan otonomi perguruan tinggi adalah kemandirian perguruan tinggi untuk mengelola sendiri lembaganya (Dirjen Pendidikan Tinggi, 2008).

Perubahan pengelolaan pendidikan memberikan kebebasan pada para pengelola organisasi pendidikan untuk memanfaatkan sumber daya yang dimiliki dan kebebasan mendesain sistem pembelajaran yang menjadi pembeda dengan sesama organisasi pendidikan lainnya. Kondisi ini menunjukkan bahwa yang semula organisasi pendidikan bersifat reaktif sekarang bersifat kompetitif, konsekuensi tersebut menuntut organisasi pendidikan tinggi, khususnya, untuk melakukan restrukturisasi pengelolaan pendidikan.

Kompetisi pendidikan di Indonesia berimbas juga pada organisasi pendidikan berbasis agama, di antaranya IAIN (Institut Agama Islam Negeri) yang telah mengalami perubahan status menjadi Universitas Islam Negeri (UIN). Perubahan IAIN menjadi UIN dideklarasikan pada tanggal 14 Oktober 2004 oleh Menko Kesra Prof. HA Malik Fajar, sebagai tindak lanjut dari SK Presiden No.50 Tahun 2004, 21 Juni 2004.

Dalam rangka menyesuaikan diri dengan Higher Education Long Term Strategy (HELTS) 2003-2010, maka salah satu ciri khasnya adalah penggunaan teknologi informasi untuk mendukung proses pembelajaran. Salah satunya di UIN Sunan Kalijaga, selain penerapan active learning, saat ini pembuatan bahan ajar diwajibkan selain menggunakan buku, juga membuat $C D$ ajar. Selain itu untuk proses pemilihan mata kuliah dilakukan secara online menggunakan internet sehingga fokus pengembangan tentang pengelolaan $e$-learning sesuai dengan program perguruan tinggi Islam dalam memantapkan kondisinya untuk mampu berkompetisi secara nasional dan internasional. Berkaitan dengan pelaksanaan $e$-learning, kondisi yang timbul adalah belum dilaksanakannya semua proses pembelajaran menggunakan $e$ learning. Sosialisasi yang dilakukan oleh Pokja Akademik tidak dilanjuti dengan proses akuntabilitas yang mampu menjaga agar keberhasilan atau kegagalan proses implementasi e-learning terukur.

Proses akuntabilitas dapat diwujudkan dengan pembentukan penjaminan mutu khusus e-learning. Saat ini penjaminan mutu (quality assurance) hanya melakukan audit pada proses administrasi pembelajaran. Statrategi pembelajaran menggunakan e-learning tidak pernah dilakukan, sehingga dapat dikatakan pelaksanaann e-learning di perguruan tinggi islam tersebut tidak terpantau kegagalan maupu keberhasilannya. Sehingga proses umpan balik dari proses tersebut juga tidak pernah dirancang.

Kurangnya perhatian pada unsur-unsur yang cukup kritis dalam organisasi dalam mendukung implementasi e-learning ditataran praktisi pendidikan kurang 
memuaskan, terutama untuk mendukung perlunya proses pengelolaan (management) perubahan yang inherent untuk menegakkan inovasi $e$-learning. Terbukti bahwa beberapa penelitian menunjukkan adanya kesenjangan pengalaman praktisi dan akumulasi pemahaman yang dimiliki (Khan, 2005). Pada beberapa penelitian secara jelas menyatakan perlu adanya penelitian yang integratif pada topik-topik profesional dan praktik. Hasil pada fokus pengembangan ini akan mendukung praktisi pendidikan untuk menggunakan $e$-learning baik pada desain dan di tingkat organisasi.

Program ini merupakan project penelitian menggunakan pendekatan kritis yang tujuannya pada strategi holistik, konsultatif, dan menekankan perspektif emansipatori. Dalam rangka melakukan penelitian menggunakan perspektif yang cukup menyeluruh, maka dilakukan pada seting organisasi yang kompleks. Dapat disimpulkan bahwa tujuan penelitian berfokus pada CSF (critical success factors) dalame-learning, sehingga bila dihasilkan suatu model holistik tentang kerangka kerja studi e-learning dapat diberlakukan pada semua institusi perguruan tinggi Islam di lingkungan Departemen Agama.

CSF dapat didefinisikan sebagai sesuatu yang dimiliki dalam pekerjaan seseorang yang harus dilakukan secara benar, agar organisasi berkembang mengindikasikan bahwa pengelola (manajemen) harus tetap menjaga agar faktorfaktor ini selalu nampak di depan mata. Dalam tataran kebijakan faktor-faktor tersebut digambarkan sebagai komponen-komponen strategi tempat organisasi harus mampu mengatasi kompetisi.

Identifikasi CSF pada situasi khusus, misalnya pada perubahan situasi yang distimulasi oleh pengenalan $e$-learning, adalah alat fundamental dalam memperoleh pemahaman holistik tentang proses sehingga CSF merupakan alat penting dalam merancang keberhasilan strategi implementasi. CSF sebagai gambaran kriteria yang lebih besar bahwa organisasi harus memastikan keberhasilan e-learning. Konsekuensinya, analisis CFS dapat dikaitkan sebagai pendekatan yang paling sesuai untuk merencanakan dan mengelola pengenalan e-learning. Aksi-aksi atau strategi yang diadopsi dalam mengimplementasi e-learning harus dikaitkan dengan CSF.

Permasalahan fundamental pada analisis CSF pada kasus ini, adalah evaluasi faktor-faktor yang dibatasi hanya pada e-learning, daripada menempatkan fokus yang lebih luas pada indikator performansi program pembelajaran keseluruhan pada perguruan tinggi Islam. Kekhususan tujuan tersebut membawa identifikasi elemenelemen yang krusial untuk keberhasilan pengelolaan e-learning. Dalam usaha memperjelas standar khusus tersebut, CSF mewakili sejumlah kecil indikator-indikator kunci yang jika menujukkan kemajuan yang memuaskan dalam pencapaian sejumlah 
indikator tersebut, secara umum organisasi dipandang berhasil mencapai perbaikan kualitas.

Analisis CSF dapat menjadi metode yang berguna untuk mengubah pandanganpandangan abstrak tentang desain, pengembangan dan implementasi program $e$ learning menjadi strategi yang lebih jelas dan terbuka (McPherson \& Nunes, 2004). Dalam studi ini analisis CSF dimulai dengan karakterisasi lima aspek fundamental pembelajaran menggunakan e-learning, yaitu : organisasi, teknologi, rancangan kurikulum, rancangan sistem pendidikan dan proses penyampaian bahan ajar menggunakan e-learning.

Penjaminan mutu (quality assurance) untuk perguruan tinggi adalah istilah yang memiliki konotasi dalam hal penekanan kualitas akuntabilitas yang merupakan hasil usaha perbaikan kualitas (quality improvement) (Harley and Knight, 1996). Kenyataannya, kualitas yang menunjukkan ukuran akuntabilitas penggunaan $e$ learning di perguruan tinggi Islam belum diterapkan sehingga tidak dapat membantu mengembangkan pemahaman proses implementasi $e$-learning, yang sebenarnya diperlukan untuk proses kemajuan implementasi. Hubungan antara proses dan kemajuan (improvement) ditunjukkan pada gambar 1.

Gambar 1.

Hubungan antara proses dan kemajuan implementasi e-learning

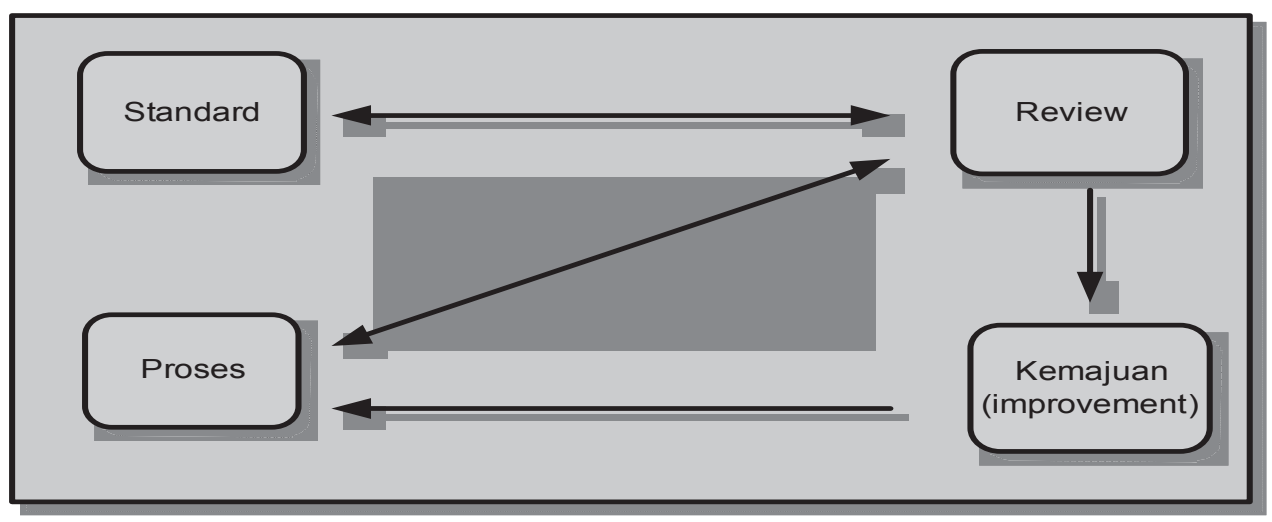

Gambar di atas adalah model sederhana penjaminan mutu (quality assurance) dari suatu proses yang dapat diterapkan dalam berbagai konteks. Kali ini digunakan untuk memahami sejauhmana universitas menjamin kualitas suatu proses dalam rangka memperbaiki dan memahami lebih baik suatu standar-standar kualitas. Di kotak kiri bawah pada model, dipahami sebagai pengembangan unsur-unsur dan proses 
pengajaran (tabel 1.), yang merupakan fokus reviu aktivitas dan akan didiskusikan lebih detil di bawah. Pada kotak kanan atas mengidentifikasi aspek-aspek reflektif dari model. Melalui refleksi, khususnya periode lingkaran (cyclical) dari suatu refleksi, dengan hasil (outcomes) awal dapat dibandingkan dengan hasil berikutnya, ini merupakan pemahaman dari kealamiahan pengembangan suatu proses, yang tentu saja membolehkan dilakukannya perbaikan atau kemajuan (pada gambar, di kotak kanan bawah). Di saat yang bersamaan standar-standar minimum pada masing-masing bagian proses (di kotak kiri atas pada gambar), dapat diartikulasikan karena review pada proses memfasilitasi pemahaman tentang kualitas proses.

Tabel 1. Pengembangan unsur-unsur dan proses pembelajaran

\begin{tabular}{ll}
\hline No & $\begin{array}{c}\text { Tahapan-tahapan kunci dalam proses pengembangan } \\
\text { dan pembelajaran }\end{array}$ \\
\hline $\mathbf{1}$ & $\begin{array}{l}\text { Keputusan untuk mengembangkan atau melakukan } \\
\text { pengembangan kembali kegiatan menggunakan ICT } \\
\text { (Information and Communication Technology) }\end{array}$ \\
$\mathbf{2}$ & $\begin{array}{l}\text { Keputusan perencanaan dan pengusulan yang } \\
\text { mempertimbangkan permasalahan terkait proses } \\
\text { pembelajaran dan pengajaran (Teaching-Learning), yaitu } \\
\text { objektivitas, pengukuran aktivitas pembelajaran hasil, } \\
\text { ketersediaan ICT, sustainability (keberlanjutan) dan } \\
\text { ketersediaan sumber daya manusia serta pengelolaannya }\end{array}$ \\
& $\begin{array}{l}\text { untuk pengembangan. } \\
\text { Keputusan pengembangan dan desain-termasuk strategi } \\
\text { pengukuran dan usaha untuk selalu mencoba materi- } \\
\text { materi atau aktivitas-aktivitas baru }\end{array}$ \\
& Pembelajaran, pengajaran, pengukuran \\
$\mathbf{4}$ & Keputusan-keputusan tentang evaluasi. \\
$\mathbf{5}$
\end{tabular}

Di tingkat universitas, kualitas atau mutu perbaikan e-learning dapat difasilitasi jika aktivitas diperoleh dari pelaksanaan e-learning ke dalam rancangan perkuliahan. Implikasi proses tersebut dikumpulkan lalu dianalisis di tingkat fakultas, dan diintegrasikan ke dalam perencanaan tahun selanjutnya. Analisis tentang informasi ini dibutuhkan untuk memastikan implikasinya bagi rancangan perkuliahan individual dipertimbangkan oleh proses administrasi akademik fakultas. Sebagai contoh, "Apa sajakah permasalahan beban kerja dan biaya yang dibutuhkan untuk staf dalam 
mengembangkan material-material dan aktivitas e-learning?"

Berdasarkan penelusuran literatur dan reviu penelitian dan model tentang $e$ learning berfokus pada perangkat keras (hardware) (McPherson, 2003), sehingga belum pernah ada yang meneliti tentang e-learning dengan memadukan teknik konsultatif dan emansipatoris, maka diaplikasikan kerangka kerja penelitian sebagai berikut : (1) berawal dari pertanyaan penelitian; (2) dilanjutkan pada reviu literatur; (3) menghasilkan formulasi kerangka kerja teoritikal e-learning;(4) yang menurunkan pemahaman dan penegakan CSF (critical success factors) untuk e-learning; (5) melakukan kompilasi dan analisis data beraasarkan focus group di masing-masing universitas Islam; (6) menghasilkan koleksi data; (7) terakhir dilakukan analisa data. Produk akhir adalah menghasilkan model tentang kerangka kerja e-learning yang menekankan pada CSF.

\section{Metode Penelitian}

Penelitian dilakukan di empat institusi pergutuan tinggi Islam, yaitu UIN Sunan Kalijaga, UIN Syarif Hidayatullah, UIN Imam Maliki, dan UIN Sunan Gunung Djati. Waktu penelitian untuk pengambilan data dilaksanakan selama tiga bulan dari bulan September tanggal 1 hingga 26 November 2010. Subjek penelitian terdiri dari 15 orang yang terdiri dari para Pembantu Rektor 1, Para Direktur Akademik (UIN Imam Maliki dan UIN Syarif Hidayatullah), Ketua Penjaminan Mutu (UIN Imam Maliki dan UIN Syarif Hidayatullah) dan Ketua Puskom, serta beberapa mahasiswa. Pemilihan subjek penelitian disesuaikan dengan karakteristik yang telah ditentukan, yaitu: representative kebijakan pusat yang mengkoordinir aspek akademik, yaitu Pembantu Rektor 1 (bidang akademik); pimpinan direktorat akademik; Ketua penjaminan mutu, karena pengelolaan mutu (quality) pembelajaran dikoordinasi oleh unit penjaminan mutu; Ketua Puskom sebagai koordinator operator Information Technology; dan beberapa mahasiswa, sebagai pengguna sehingga pemilihan subjek penelitian menggunakan purposive sampling technique.

Penelitian kritis dipilih sebagai pendekatan generik untuk studi ini, karena pendekatan ini mampu mengakomodir perspektif studi ini yaitu holistik, konsultatif dan emansipatoris. Tujuan penelitian ini adalah melakukan pendekatan studi kasus, untuk melakukan probing lebih mendalam tentang implementasi e-learning pada empat institusi perguruan tinggi Islam, yang tidak dapat dipisahkan dari budaya organisasi individual, kebijakan, dan ideologi.

Pendekatan inquiry bersifat kooperatif, didasarkan pada wawancara kelompok yang terfokus, karena bentuk penelitian partisipatif yang unik dan 
komprehensif. Wawancara mendalam pada kelompok dilakukan di masing-masing UIN, karena tidak dimungkinkan dilakukannya focus group discussion.

Tujuan penelitian ini didefinisikan melalui formulasipertanyaan penelitian berikut: “Apa saja Critical Success Factors (CSF) yang dipersyaratkan untuk mendukung rancangan, pengembangan, implementasi dan pengelolaan $e$-learning di institusi perguruan tinggi?' Terkait dengan pertanyaan ini, studi ini berkonsentrasi pada CSF yang dipersyaratkan untuk sistem aktivitas manusia dalam mendukung e-learning. Oleh karena itu tujuan khusus penelitian adalah untuk :

a. Menghasilkan model teoritik yang digunakan untuk memahami $e$-learning

b. Menganalisa, mengaitkan dan mengelompokkan CSF sebagai suatu pedoman untuk perubahan institusi dan mendukung gagasan-gagasan baru

c. Meninjau, dan mengadaptasi kerangka kerja e-learning untuk memandu penelitian dan praktik e-learning selanjutnya.

Jenis pendekatan untuk studi ini menggunakan pendekatan kualitatif, sehingga pengumpulan data menggunakan teknik observasi, melakukan wawancara yaitu menggunakan wawacara semi terstruktur dengan alat bantu berupa alat perekam digital, dan mentranskip wawancara, melakukan focus group interview, menggunakan alat perekam digital, dan mentranskip data, melakukan dokumentasi berupa pencatatan jurnal yang dilakukan selama pengambilan data; menganalisis dokumen publik (berupa peraturan, progress report masing-masing UIN, dokumentasi SOP, website, dan buku induk pengembangan e-learning) serta fotofoto yang relevan dengan tema penelitian.

Proses analisis data melibatkan persiapan data untuk dianalisis, mengaitkan hasil analisis yang berbeda, bergerak lebih dalam lagi menuju pemahaman data, menampilkan data, melakukan interpretasi yang lebih luas dari data.

\section{Hasil dan Pembahasan}

Berdasarkan pengolahan data, analisa dan interpretasi data diperoleh gambaran analisis data melalui pengelompokkan respons pada proses wawancara, berupa peta kognitifCSF.

Identifikasi dan formulasi respon individual tentang CSF dalam peta kognitif di atas, dihasilkan dari proses koding kata-kata dan gagasan yang memiliki makna sama dari para subjek penelitian. Proses pengelompokkan bukan bersifat kuantitatif, melainkan dihasilkan dari pendekatan koding kualitatif. 


\section{a. Kepemimpinan, struktural dan permasalahan budaya}

Kebijakan pengelolaan organisasional mempengaruhi tanggungjawab untuk setting akademik dan pendidikan melalui perbaikan prosedur administratif serta ketersediaan sumber daya, dan berdampak pada model pedagogic realistic; juga pada akhirnya berdampak pada desain $e$-learning. Persamaan dengan banyak setting pendidikan lain adalah transisi dari metode penyampaian tradisional ke lingkungan $e$-learning harus melibatkan perubahan pengelolaan. Proses ini cukup sulit yang mempersyaratkan kepemimpinan yang kuat sekaligus mendukung (supportive), dan perubahan dalam struktur-budaya organisasi. Komponen ini diidentifikasi oleh semua subjek dalam peta kognitif.

Budaya organisasi difahami sebagai nilai-nilai (values), keyakinankeyakinan (beliefs), filosofis, cara untuk berperilaku dan berinteraksi dengan orang lain, dengan menampilkan keanggotaan dari organisasi tertentu. Universitas yang masih tradisional seringkali memandang institusi perguruan tinggi sebagai institusi kolegial yang terdiri dari para pelajar yang memiliki tujuan untuk berkumpul, menghasilkan dan mempresentasikan pengetahuan (McPherson \& Nunes, 2006). Staf akademik selalu berpikir universitas sebagai senior management, senat, dan gaya administrasi terpusat. Berdasarkan hasil interview, para subjek mengidentifikasi kepemimpinan universitas, dukungan, kesediaan untuk memberikan bantuan dana sebagai cara untuk mengenali (recogni e) dan pemberian imbalan sebagai faktor utama dari CSF.

Di sisi lain, untuk mengelola dan mendesain proses administrasi dalam institusi perguruan tinggi, universitas harus keluar atau membangun jejaring, karena diharapkan berjalan sesuai visi dan misi organisasi, kebijakan strategi dan organisasional dan nasional, dalam rangka memanfaatkan pendanaan dan sumber daya yang tersedia.

Mahasiswa dan administrator sebagai representasi universitas (Huatori dan Wilson, 2001), secara seksama perlu mempertimbangkan kebutuhankebutuhan pembelajaran dan hasil (outcomes) sama baiknya dengan mengelola harapan yang diidentifikasikan sebagai CSF yang fundamental. Dapat dilihat bahwa sejumlah pandangan berkontribusi pada struktur organisasi dan budaya institusi perguruan tinggi, dan sejak antusiasme untuk mengenalkan e-learning tidak universal, berbagai perspektif dibutuhkan jika $e$-learning ingin mencapai keberhasilan. Oleh karena itu subjek mengidentifikasi komunikasi yang baik dan kepemimpinan institusional sebagai inti CSF. Untuk melengkapi ini, beberapa subjek mengidentifikasi perlunya dukungan sebagai sesuatu yang krusial. 
Analisis identifikasi CSF yang mengelompokkan kepemimpinan, struktural dan permasalahan budaya secara jelas menggambarkan perhatian pada kenyataan, bahwa organisasi yang mengharapkan untuk mengimplementasi $e$ learning, seharusnya terlebih dahulu harus familiar dengan budaya organisasi yang dimiliki, struktur yang dimiliki, dan strategi menghadapi konflik, sebelum lebih jauh merancang, mengembangkan, dan mengimplementasi solusi $e$ learning. Lebih jauh lagi, semakin jelas bahwa permasalahan manusia kaitannya dengan partisipasi, informasi, pelatihan, dan komunikasi, sebagai keterlibatan stakeholder cukup fundamental ketika merumuskan tipe pembelajaran.

\section{b. Rancangan (desain) e-learning}

Melalui penggunaan pandangan strategik, institusi perguruan tinggi memiliki kekuatan mutlak di tingkat organisasi untuk memfasilitasi perkembangan beberapa gagasan. Bagaimanapun juga mengenali implementasi lingkungan e-learning berarti tidak hanya sekedar mendesain beberapa halaman web, dan ini sangat krusial untuk keberhasilan setiap gagasan yang berkaitan tentang e-learning. Saat ini, beberapa pendekatan secarakeseluruhan belum cukup untuk mendukung secara efektif proses pembelajaran. Rancangan dan perkembangan lingkungan pembelajaran online melibatkan kolaborasi antara pendidik, pemateri ahli, dan ahli teknologi informasi, dilibatkan dalam proses perancangan instruksional yang pemilik gagasan secara primer dilibatkan dalam rancangan kurikulum, selanjutnya dikembangkan olehbidang teknis ditataran aplikasi aktual. Oleh karena itu, komunikasi antara agen-agen ini menjadi suatu kepentingan mutlak. Hanya saja masing-masing agen selalu berbicara dengan istilah-istilah khusus tekhnologi yang hanya difahami sendiri, artinya tidak selalu siap memahami permasalahan bidang lain, yang bukan bidangnya, sehingga pendekatan berdasarkan efisiensi projek harus diintegrasikan dan didukung dialog antara kelompok-kelompok yang berbeda ini.

Hal ini juga merefleksikan sistem pengenalan yang digunakan bahwa pengelolaan proyek yang baik harus juga menjadi inti keberhasilan proses rancangan. Subjek penelitian juga mengharapkan saran eksplisit dari organisasi dan sektornya, dalam bentuk rancangan, pengembangan, kemampuan mengakses, kegunaan dan pengujian panduan.

Hasil tersebut kenyataannya memang difokuskan pada kematangan persiapan dalam mendesain e-learning. Ditemukan bahwa impelemtasi $e$ learning tidak hanya sekedar membuat proposal inovatif dan bersifat bottom up, namun lebih dari itu, praktisi mengharapkan kepemimpinan, dukungan dan 
pengelolaan proyek dari universitas, dengan kata lain perlu juga dukungan dari pengelola pusat universitas. Dapat dikatakan, bahwa e-learning tidak memerlukan pembuktian lagi, sebaliknya membutuhkan untuk hadir dari lingkungan yang dapat mendesain secara tepat, dikembangkan dari anggota tim yang multidisipliner dalam pengelolaan desain e-learning yang tepat.

\section{c. Teknologi yang mendukung e-learning}

Institusi pendidikan perguruan tinggi telah menghadapi beberapa tantangan yang distimulasi dari evolusi yang sangat cepat dari Information and Communication Technology (ICT). ICT merupakan sarana vital untuk $e$ learning, universitas harus memutuskan jenis sistem, sumber daya dan infrastruktur untuk mendukung tipe pembelajaran ini yang cukup adekuat. Hasil temuan mengidentifikasi CFS terkait cukup erat dengan rancangan infrastruktur yang sesuai, yang baik dalam hal keamanan, proteksi data, perlindungan properti intelektual, transmisi data dan proses komunikasi yang adekuat. Dalam hal ini tentu saja CSF harus selalu dihubungkan dengan pendekatan pembelajaran yang dipusatkan pada ICT. Lebih jauh lagi dari temuan penelitian, terefleksikan kebutuhan untuk dukungan teknikal yang efektif dalam menggunakan infrastruktur ICT, begitu pula dengan perawatannya (maintenance).

Lebih menarik lagi, ditemukan juga bahwa untuk menekankan pada pentingnya pembedaan antara $e$-learning sebagai proses pembelajaran dan teknologi yang mendukung pembelajaran. Terlihat menunjukkan perlunya tingkat berpikir yang cukup matang di komunitas e-learning, untuk mampu membedakan antara ilmu komputer dengan electronic and control engineering sehingga keberhasilan e-learning tidak dapat diatribusikan hanya untuk pemanfaatan tekhnologi terbaru, tetapi lebih jauh tergantung pada apa yang telah dilakukan dengan ICT baik dalam hal rancangan (design) maupun proses pembelajaran.

\section{d. Proses Perkuliahan (penyampaian materi) menggunakan metode $e$-learning}

Kesempatan baru diberikan untuk mengakses informasi dan komunikasi menggunakan ICT, bersamaan dengan munculnnya berpikir pedagogik, telah memungkinkan institusi perguruan tinggi untuk merancang dan menghantarkan program e-learning baru, perkuliahan, dan penyusunan modul. Proses transformasi, perkuliahan, modul, dan terkadang keseluruhan program-program yang dikombinasikan atau multimodal dari organisasi diperlukan perubahan yang lebih luas untuk pengelolaan informasi, perilaku organisasi, pendekatan pedagogik 
dan sikap karyawan (Duke, 2002).

Telah terdidentifikasi bahwa CSF disini mengimplikasikan perlunya evaluasi yang menggaransi penyampaian melalui panduan praktik terbaik, pelatihan yang tepat dan dukungan untuk tutor dan mahasiswa, memilih model pembelajaran yang tepat untuke-learning dan menegakkan standar pendidikan dan pemetaan penyampaian perkuliahan yang berdasarkan pada etika. Akhirnya dan bukti yang lebih jauh tentang kematangan di perencanaan e-learning sebagai pendekatan pendidikan, diidentifikasi perlunya reward dari universitas untuk menghargai para tenaga pengajar yang telah melaksanakan e-learning dalam proses penyampaian materi ajar.

\section{Simpulan}

Penelitian ini berusaha menggambarkan dan mendiskusikan tema besar dalam organisasi terkait CSF yang memiliki dampak kuat dalam perancangan, pengembangan dan penyampaian $e$-learning. CSF dipisahkan ke dalam empat kelompok (kluster), yaitu : kepemimpinan, permasalahan struktural dan kultural; rancangan; teknologi dan penyampaian materi. Bagaimanapun juga analisis dan interpretasi CSF untuk mengindikasikan bahwa meskipun banyak akademisi telah mengenali kebutuhan untuk berubah, tidak selalu diterima secara universal, salah satunya $e$-learning yang tidak selalu secara adekuat didukung. Akademisi tidak mungkin bisa terlibat pada visi organisasi tanpa kesempatan nyata untuk berdiskusi dan bernegosiasi. Di sini membutuhkan kepemimpinan, dukungan, recognition dan diskusi internal yang menujukkan kematangan berfikir dan praktik profesional tentang e-learning .

Dianalisis pula dalam penelitian ini mengenai permalasahan mutu (quality) dan pengelolaan untuk mengintegrasikan e-learning ke dalam sistem pembelajaran dan pengajaran dalam lingkungan universitas berbasis kampus. Gambaran penelitian ini menunjukkan bahwa stakeholders dipersiapkan untuk akrab dengan e-learning. Melekatkan e-learning ke dalam institusi perguruan tinggi menimbulkan sejumlah tantangan untuk kualitas pengelolaannya, sehingga jika implementasi pembelajaran online ditargetkan berhasil, maka universitas harus mampu mengelola proses perubahan melalui diskusi yang disepakati, dukungan strategi yang tepat, lalu merealisasikannya melalui komitment bersama. 


\section{Daftar Pustaka}

Duke, C.(2002). Managing the Learning University., Singapore : Sage Pub.

Harley, J. \& Knight. (1996). Co-operative Inquiry: Research into the Human Condition. London: Sage.

Huatori, M.L. \& Wilson, T.D. (2001). "Determining organizational information needs: the critical success factors approach", Information Research, Vol .6. No. 3, avaible at: http://InformationR.net/ir/6-3/paper108.html

McPherson, M.A(2003). Planning for success in e-learning in HE: a strategic view. Proceedings of the $2^{\text {nd }}$ International coference on emerging Telecomunications Tekhnologies and Applications and the $4^{\text {th }}$ Conference on Virtual University (ICETA 2003), 449-452.

Spil, A.A.M,. dan Salmela, H. (2003). The Fall of strategic information systems planning and the rise of a dynamic IS strategy. Proceedings of the $22^{\text {nd }}$ Information System Research Seminar in Scandinavia (IRIS 22). Available at: http://iris22. It.jyu.fi/iris22/pub.Spilsalmela_R301.pdf(diakses 15 Februari 2010). 